DOI: https://doi.org/10.47405/mjssh.v6i2.663

\begin{tabular}{|c|c|}
\hline$x=$ & Malaysian Journal of Social Sciences and Humanities (MJSSH) \\
\hline Malaysian Journal of & Volume 6, Issue 2, February 2021 \\
\hline (MJ-ssH) & e-ISSN : 2504-8562 \\
\hline & $\begin{array}{l}\text { Journal home page: } \\
\text { www.msocialsciences.com }\end{array}$ \\
\hline
\end{tabular}

\title{
Hubungan Iklim Organisasi Sekolah dengan Burnout Guru Sekolah Menengah
}

\author{
Leong Shen Yen ${ }^{1}$, Norazah Mohd Nordin ${ }^{1}$ \\ ${ }^{1}$ Fakulti Pendidikan, Universiti Kebangsaan Malaysia (UKM) \\ Correspondence: Leong Shen Yen (shyen13@gmail.com)
}

\begin{abstract}
Abstrak
Artikel ini bertujuan untuk mengenal pasti tahap iklim organisasi sekolah dan tahap burnout guru serta hubungan iklim organisasi sekolah dengan burnout guru dalam kalangan guru sekolah menengah di daerah Subis, Sarawak. Kajian in adalah bersifat kuantitatif yang mendadaptasi dan menyesuaikan soal selidik Organisational Climate Index (OCI) dan Maslach Burnout Index (MBI) mengikut konteks kajian. Sampel kajian terdiri daripada 167 orang guru yang telah dipilih dengan menggunakan pensampelan rawak berstrata daripada 5 buah sekolah menengah di daerah Subis. Perisian SPSS versi 26 digunakan untuk menganalisis data dengan statistik deskriptif dan inferensi. Hasil kajian menunjukkan bahawa tahap iklim organisasi sekolah berada pada tahap yang sederhana $(\min =2.58$, $\mathrm{SP}=379$ ). Tahap burnout guru dalam kalangan guru sekolah menengah berada pada tahap sederhana rendah $(\mathrm{min}=2.61, \mathrm{SP}=.466$ ). Analisis korelasi pearson yang menjelaskan hubungan iklim organisasi sekolah dengan burnout guru sekolah menengah daerah Subis pula mencatatkan korelasi yang tidak signifikan ( $\mathrm{r}=.053)$ pada tahap sangat rendah. Analisis regresi berganda stepwise mendapati tiada dimensi iklim organisasi sekolah yang meramalkan tahap burnout $[\mathrm{F}(4,162)=0.689, \mathrm{p}<0.05]$. Dapatan daripada kajian ini menunjukkan bahawa iklim organisasi sekolah adalah kurang terbuka kerana pihak pentadbiran sekolah kurang memberi dan mendapat maklum balas daripada pihak ibu bapa dan pihak luar. Kajian lapangan perlu merangkumi aspek iklim sekolah yang lain seperti penglibatan murid, komitmen guru dan efikasi kendiri guru. Iklim organisasi sekolah yang rendah memberikan implikasi terhadap pengetua untuk meningkatkan akauntabiliti dan ketelusan kepada pihak ibu bapa serta bersikap terbuka untuk menerima pandangan daripada pihak lain.
\end{abstract}

Kata kunci: iklim organisasi sekolah, burnout, guru sekolah menengah

\section{School Organizational Climate In Relation To Secondary School Teacher Burnout}

\begin{abstract}
This present qualitative study was conducted to find out level of school organisational climate, level of teacher burnout and the relationship between these variables. The Organisational Climate Index (OCI) and Maslach Burnout Index (MBI) instrument surveys were translated and adapted to fit the local context. One hundred and sixty-seven teachers from the five national secondary schools of the rural district of Subis, Sarawak participated in this study. Descriptive analysis found that school organisational climate was at an average level $(\min =2.58, \mathrm{SD}=.379)$. while teacher burnout was at an overall low $(\mathrm{min}=2.61, \mathrm{SD}=.466)$. Pearson correlation analysis showed no significant relation between school organisational climate and teacher burnout $(r=.053)$ while multiple regression analysis showed that sub dimensions of school organisational climate did not significantly predict teacher burnout $[\mathrm{F}(4$, $162)=0.689, \mathrm{p}<0.05]$. Study findings show that the low level of school organisational climate
\end{abstract}


indicates a lack of engagement by school admistrators with parents and outside parties. Further studies should include other aspects of school organisation climates such as student involvement, teacher commitment and teacher self-efficacy. This study has implications for principals to increase levels of accountability and transparency towards parents, along with an open attitude to receiving opinions from stakeholders.

Keywords: organizational climate, burnout, secondary school teachers, rural schools, Subis district

\section{Pengenalan}

Penyelidikan awal mengenai burnout menunjukkan bahawa gejala burnout adalah dominan dalam sektor perkhidmatan sumber manusia - seperti penjagaan kesihatan, perkhidmatan sosial, dan kesihatan mental, serta sektor pendidikan yang melibatkan kerja intensif dengan orang selain daripada mengandungi cabaran emosi yang tinggi. Profesion keguruan adalah salah satu bentuk perkhidmatan awam dan sosial yang agak menuntut dari segi emosional. Guru merasa dicabar oleh beban kerja yang tinggi dan tugas berat, tanpa mengira perbezaan dalam keadaan kerja setiap negara, seperti gaji, keselamatan kerja atau kedudukan sosial (Bottiani, 2019). Dalam dekad terakhir, Malaysia telah memperdalam reformasi pendidikan asasnya melalui perubahan ketara terhadap sistem sekolah dan sistem penilaian guru. Perubahan ini menyebabkan tekanan kepada guru lebih banyak, yang pada gilirannya lebih cenderung mengalami emosi negatif dan ketidakselesaan fizikal (Mohamad, 2015; Tajulashikin et al., 2013). Antara punca utama yang menyebabkan tekanan dalam kalangan guru di tempat kerja ialah bebanan tugas (Ambatong et al, 2015; Wahab, 2018). Halim (2013) pula menyatakan bahawa faktor lain yang menyumbang kepada tekanan guru juga dikaitkan dengan aspek tingkah laku pelajar diikuti juga dengan kekurangan status di tempat kerja, ketidakstabilan kecemerlangan prestasi, kekurangan peluang untuk naik pangkat, hubungan yang tidak baik dengan rakan sekerja, sokongan yang tidak mencukupi serta tahap motivasi pelajar yang rendah (Akhlaq et al., 2010; Mohamad, 2015).

Di Malaysia, guru didapati untuk mempunyai prevalensi kemurungan tinggi (43.0\%), kebimbangan (68.0\%) dan gejala stress (32.3\%) (Othman \& Sivasubramaniam, 2019). Oleh kerana budaya menilai pencapaian ini adalah suatu norma (Saeki, 2018), guru dikehendaki untuk memastikan pencapaian murid meningkat (Hattie, 2012; Lingard et al., 2016). Ini menambah beban ke atas bahu guru untuk memastikan murid mendapat keputusan yang cemerlang semasa peperiksaan dan meningkatkan kebarangkalian guru untuk mengalami burnout akibat penambahan kertas kerja yang mengambil masa dan tidak relevan kepada perkembangan pembelajaran murid (Petrie et al., 2018; Rooney, 2015). Jarvis (2002) mendapati bahawa 25\% guru mempunyai masalah kesihatan, seperti hipertensi, insomnia, kemurungan, dan gangguan gastrousus.

Emosi memainkan peranan penting dalam merubah kepercayaan seorang guru (Malinen, 2016). Penuntutan emosi ini selalu dikait dengan kesan negatif seperti kelesuan guru, ketidakpuasan hati terhadap kerja dan juga kurangnya motivasi guru (Kinman et al., 2011; Kunter et al., 2011). Guru yang sengaja menahan emosi sebenar yang dialami demi kebahagiaan murid (Shoval et al., 2010) akan secara beransur-ansur mengalami penurunan terhadap kebajikan (kesihatan fizikal dan mental) diri serta sikap terhadap kerja (Grandey \& Gabriel, 2015; Hulsheger \& Schewe, 2011). Keletihan guru dikaitkan dengan peningkatan ketidakhadiran, pergantian, niat untuk meninggalkan kerjaya, sikap kerja yang negatif, dan penurunan prestasi pengajaran.

Beberapa kajian mendapati burnout guru dikaitkan dengan keyakinan diri, iklim sekolah, dan iklim bilik darjah (Bianchi et al., 2016; Dorman, 2003; Grayson dan Alvarez, 2008). Guru di iklim sekolah yang disokong oleh kepemimpinan kolegial pengetua dan tahap profesionalisme yang tinggi akan menganggap diri mereka mempunyai tahap tekanan yang lebih rendah (Hu et al., 2019). Walaupun kajian lepas menunjukkan bahawa iklim organisasi berkait dengan tekanan guru (Collie et al, 2012; Hu et al., 2019), tetapi bukti hubungan antara iklim organisasi dan burnout di kalangan guru Malaysia 
dibatasi oleh fakta bahawa kurangnya kajian empirikal telah dilakukan yang menggunakan kerangka bertingkat untuk menilai hubungan tahap iklim sekolah di kawasan luar bandar dengan burnout.

\section{Tujuan dan Objektif Kajian}

Tujuan kajian ini adalah untuk mengenal pasti tahap burnout guru dan hubungannya dengan iklim organisasi sekolah di sekolah menengah daerah Subis, Sarawak manakala objektif kajian ini adalah untuk:

i. Mengenal pasti tahap burnout dalam kalangan guru sekolah menengah daerah Subis, Sarawak.

ii. Mengenal pasti tahap iklim organisasi sekolah guru sekolah menengah di daerah Subis, Sarawak.

iii. Mengenal pasti hubungan antara iklim organisasi sekolah dengan tahap burnout guru sekolah menengah di daerah Subis

iv. Mengenal pasti dimensi iklim organisasi sekolah yang paling menyumbang kepada tahap burnout guru sekolah menengah daerah Subis, Sarawak?

\section{Hipotesis Kajian}

Hipotesis kajian adalah seperti berikut:

$\mathrm{H}_{0} 1$ : Tiada tahap burnout yang signifikan dialami oleh guru sekolah menengah daerah Subis, Sarawak.

$\mathrm{H}_{0} 2$ : Tiada tahap iklim organisasi sekolah yang signifikan sekolah menengah daerah Subis, Sarawak.

$\mathrm{H}_{0} 3$ : Tiada hubungan signifikan antara iklim organisasi sekolah dengan tahap burnout dalam kalangan guru di daerah Subis, Sarawak.

$\mathrm{H}_{0} 3^{1}$ : Tiada dimensi iklim organisasi sekolah yang paling menyumbang kepada tahap burnout guru sekolah menengah daerah Subis, Sarawak

\section{Tinjauan Literatur}

\section{Burnout}

Burnout secara konseptual serupa dengan definisi tekanan pekerjaan kerana ia sering diukur oleh gejala dan ciri tekanan misalnya, keletihan, masalah kesihatan mental (Bakker \& Demerouti, 2001). Namun burnout dan tekanan berbeza kerana tekanan yang berpanjangan boleh menyebabkan munculnya sindrom burnout yang sering dicirikan oleh keletihan fizikal, emosi dan sikap (Kyriacou \& Sutcliffe, 1978). Burnout disifatkan sebagai tindak balas yang berpanjangan terhadap tekanan kerja kronik dari masa ke masa (Maslach et al., 2003), dan lebih berkaitan dengan ketidakberdayaan, dan perasaan depresi (Bottiani, 2019; Zhang, 2014). Persekitaran kerja boleh menjadi sumber tekanan, dan banyak pekerja mengalami masalah kesihatan mental yang disebabkan oleh tekanan kerja. Guru sekolah telah dilaporkan untuk mempunyai lebih banyak kemungkinan masalah kesihatan mental berbanding daripada profesion lain, termasuk akauntan, penganalisis, kakitangan kedai arak, dan kakitangan perubatan (Chaplain, 2008; Stoeber et al., 2007). Guru juga kebanyakan didapati mengalami burnout (Heinnemann et al., 2017), kemurungan (Kovess-Masfe'ty et al., 2007) dan gangguan somatik (De Simone et al., 2016). Guru sekolah dengan tekanan psikologi yang tinggi didapati menunjukkan tindak balas yang tidak sesuai, termasuk kesihatan yang buruk, ketidakhadiran, pergantian pekerjaan, dan prestasi pengajaran terjejas (Choi, 2018). Faktor organisasi yang berkaitan dengan persekitaran sekolah merangkumi kekurangan kakitangan dan peralatan, kertas kerja yang berlebihan, gaji yang tidak 
mencukupi, kekurangan peluang kemajuan, perpindahan sukarela dari satu sekolah ke sekolah lain, kekurangan sokongan pentadbiran, konflik dalam persepsi pekerjaan, dan kekaburan dalam definisi peranan (Malinen, 2016; Ford, 2019; Shackleton, 2019). Tingkah laku murid juga dilaporkan sebagai faktor utama yang menjadi sering menjadi punca kepada tekanan guru di tempat kerja diikuti dengan sokongan kakitangan, hubungan dengan ibu bapa, kompetensi peribadi dan profesional, dan sebagainya (Paulse, 2005, diambil dari Shkembi et al., 2015).

Kajian mendapati bahawa keletihan emosi dikaitkan dengan tahap sokongan tingkah laku positif yang rendah di dalam kelas, di mana guru akan mempunyai kadar teguran keras yang tinggi (Reinke et al. 2013). Di samping itu, guru yang mengalami tahap keletihan tinggi atau merasa emosi keletihan akan menunjukkan pengajaran berkualiti rendah dan mempunyai hubungan lemah (Zhang et al., 2014; Maslach \& Jackson, 1981). Tambahan itu, guru yang mempunyai keberkesanan diri yang rendah, atau kepercayaan negatif mengenai kemampuan mereka mengajar pelajar dan pengurusan tingkah laku akan menunjukkan amalan pengajaran yang kurang berkesan, serta menyebabkan pencapaian pelajar yang lebih rendah (Skaalvik \& Skaalvik, 2007). Tekanan yang dialami juga menyumbang kepada pergantian guru (Johnson et al., 2005). Kira-kira separuh daripada guru meninggalkan padang dalam 5 tahun pertama mereka, sering disebabkan oleh tekanan profesion (Ingersoll, 2002). Pendedahan berulang kali kepada kerenah pelajar dan masalah pengurusan kelas didapati untuk meningkatkan tahap tekanan dan emosi negatif guru, serta mengelirukan penilaian guru terhadap keberkesanan diri dan sokongan yang dirasakan (Aldrup et.al, 2018; Shen et. al., 2015).

\section{Iklim Organisasi Sekolah}

Dalam tinjauan literatur iklim sekolah yang dijalankan oleh Larson et. tal. (2020), konsep iklim sekolah bermula pada awal tahun 1900-an ketika ia digambarkan sebagai "semangat de korps" sekolah (Freiberg \& Stein, 1999). Menurut Goddard et al. (2015) dan Holt \& Smith (2002), iklim organisasi sekolah adalah persefahaman kolektif dalam organisasi yang dapat memberi kesan yang berkekalan terhadap operasi dan keberkesanan sekolah, sedangkan Grayson et al. (2008) menyatakan bahawa iklim organisasi sekolah terdiri daripada interaksi interpersonal antara perangai guru dan pengetua. Satu lagi definisi iklim sekolah ialah ciri sosial sekolah dari segi hubungan antara pelajar dan guru, penekanan pembelajaran dan pengajaran, nilai dan norma, dan pendekatan dan amalan bersama (Anderson, 1982; Moos, 1987; Thapa et al., 2013). Definisi Vos et al. (2012) memandang iklim organisasi sekolah sebagai bentuk tenaga yang merangkumi kualiti kehidupan organisasi yang dapat diukur.

Iklim organisasi sekolah adalah kualiti persekitaran sekolah yang berterusan yang dialami oleh guru, mempengaruhi tingkah laku mereka, dan berdasarkan persepsi kolektif guru terhadap tingkah laku dalam sebuah sekolah (Hoy dan Miskel, 2008). Iklim organisasi terdiri daripada pelbagai dimensi, dan masing-masing memusatkan perhatian terhadap aspek persekitaran dan fungsi organisasi yang berbeza (Dickson et al. 2001; McMurray et al., 2004; Nieuwoudt, 2012). Sifat dimensi-dimensi yang saling berkaitan dan bertepatan ini menjadikannya sukar untuk mencapai definisi iklim organisasi yang tepat. Grojean et al. (2004) mendefinisikan iklim organisasi sebagai persepsi amalan dan prosedur organisasi yang dikongsi di antara anggota yang memberikan petunjuk sistem normatif yang dilembagakan yang memandu tingkah laku. Ini adalah sekumpulan sifat persekitaran kerja, yang dirasakan secara langsung atau tidak langsung oleh pekerja, yang dianggap sebagai kekuatan utama dalam mempengaruhi tingkah laku pekerja (Ivancevich et al., 2008).

Penyelidikan iklim sekolah secara konsisten menyokong kesimpulan bahawa keterbukaan sekolah dan nada emosinya saling berkaitan. Keterbukaan sekolah dikaitkan dengan pengasingan pelajar yang kurang, kadar keciciran pelajar yang lebih rendah, dan kepuasan pelajar terhadap sekolah yang lebih tinggi (Hoy, 1972; Konold et al., 2018). Selain itu, iklim sekolah yang terbuka secara umumnya lebih berkesan daripada iklim tertutup, dan guru lebih banyak terlibat dalam membuat keputusan bersama (Hoy \& Sabo, 1998; Hoy et al., 1991). Keterbukaan, komitmen guru, dan kesetiaan guru (Hoy et al., 2002) dikaitkan secara positif. Iklim sekolah terbuka meningkatkan kepercayaan fakulti dan meningkatkan persepsi keadilan di sekolah (Hoy \& Tarter, 2004). 
Hubungan organisasi yang terbuka juga mempunyai kesan positif di sekolah kerana ia mempermudah proses meningkatkan pengajaran. Tidak ada mana satu iklim yang dapat menjamin pengajaran dan pembelajaran yang berkesan, kerana iklim sekolah dengan sendirinya tidak dapat mengubah program yang buruk menjadi baik atau guru yang kurang berprestasi menjadi cemerlang, tetapi iklim sekolah yang terbuka dapat memberikan suasana yang diperlukan untuk refleksi, perubahan kerjasama, dan peningkatan kendiri (Dipaola \& Hoy, 2012). Menurut Ali dan Hale (2009) guru akan bermotivasi ekstrinsik dan intrinsik dan cenderung untuk menikmati kerja apabila pengetua komited untuk menjalankan tugas. Iklim organisasi sekolah dipengaruhi secara positif oleh kepercayaan tinggi guru terhadap pengetua mereka, di mana guru mencurahkan tenaga untuk mencapai matlamat organisasi, sehingga pelajar dan guru masing-masing menikmati proses pembelajaran dan pengajaran, Walau bagaimanapun, iklim organisasi sekolah terjejas secara negatif apabila pengetua kurang berminat dengan pekerjaan guru, dan menghalang prestasi pelajar dan guru. Iklim organisasi sekolah juga boleh menjadi keburukan kerana boleh mengakibatkan " pemikiran kumpulan " yang membatasi inovasi (Punia et al. 2004, diambil dari Ghavifekr \& Pillai, 2016). Iklim sekolah dikenali sebagai penyumbang utama kepada pembangunan guru dan mempromosikan sekolah yang selamat dan menyokong (Thapa et al., 2013). Iklim sekolah yang positif telah dikaitkan dengan peningkatan pencapaian pelajar (Gaias et al., 2019). Peningkatan harga diri pelajar, konsep kendiri, dan hasil kesihatan emosi dan mental yang lain dikaitkan dengan iklim sekolah yang positif (Hoge et al., 1990; Kuperminic et al., 2001; Way et al., 2007). Kajian juga mendapati bahawa iklim sekolah positif dikaitkan dengan tahap penggunaan dadah dan masalah kesihatan mental pelajar yang lebih rendah (LaRusso et al.,2008), mengurangkan kes buli pelajar (Gregory et al., 2010), merendahkan kadar keciciran sekolah menengah (Huang et.al., 2015), memupuk pengekalan guru, serta membenarkan penglibatan dan hubungan antara staf dan pelajar (Cohen et al., 2009).

\section{Hubungan Burnout dengan Iklim Organisasi Sekolah}

Terdapat banyak bukti yang menunjukkan bahawa pekerja perkhidmatan manusia, termasuk guru sekolah mempunyai risiko burnout yang tinggi (Herman, 2017; Lavian, 2012). Persepsi guru terhadap iklim sekolah telah dikaitkan dengan burnout di kalangan guru (Grayson dan Alvarez, 2008) dan tahap komitmen kerja (Collie et. al.c, 2011). Kajian telah mendapati kekurangan sokongan sosial, kesedaran komuniti yang lemah, serta konfrontasi atau hubungan tegang di dalam organisasi sekolah merupakan sumber utama untuk burnout dalam kalangan guru (Collie et al., 2012; Perrone et al., 2019; Plantiveau et al, 2018). Shakleton (2019) mendapati faktor-faktor yang paling konsisten berkaitan dengan burnout yang dialami oleh guru adalah persepsi guru terhadap keselamatan dan sokongan sekolah dan sikap pelajar terhadap pembelajaran. Persepsi keselamatan atau sokongan yang rendah dan persepsi yang lemah terhadap minat pelajar untuk belajar dikaitkan dengan tahap burnout yang lebih tinggi tanpa bergantung kepada jantina, etnik, pengalaman, atau aspek persekitaran sekolah yang lain.

Meor (2011) mendapati hubungan yang signifikan di antara iklim kerja dengan tahap burnout guru tetapi tidak mendapati perbezaan yang signifikan di antara tahap burnout dengan jantina dan opsyen guru. Secara ringkas, iklim yang mempunyai sokongan sosial yang kuat boleh menjadi satu penghalang terhadap burnout, manakala hubungan rakan sekerja yang selalu dalam konflik akan meninggikan risiko burnout (Meor, 2011; Lim, 2014).

Terdapat perbezaan yang cukup besar antara penyumbangan guru yang tidak berpuas hati dan mempunyai keinginan untuk berhenti.berbanding dengan guru yang terlibat dan gembira kepada iklim sekolah dan pembelajaran pelajar. Guru yang berhasrat meninggalkan tempat kerja sering menunjukkan kadar burnout yang lebih besar serta penurunan usaha, motivasi dan komitmen organisasi (Conley \& You, 2009; Hakanen et al., 2006). Tingkah laku pengunduran guru ini boleh mempengaruhi iklim sekolah melalui interaksi yang tegang dengan rakan sekerja dan pelajar (Grayson \& Alvarez, 2008; Kokkinos et al., 2005), dan boleh menyebabkan peningkatan ketidakhadiran guru, kos perubatan bagi penjagaan kesihatan mental dan penurunan keberkesanan sekolah secara keseluruhan (Grayson dan Alvarez, 2008; Boström et al., 2019).

Mengikut Collie et al. (2011), iklim sekolah adalah peramal penting untuk kepuasan kerja guru kerana persepsi guru terhadap persekitaran pekerjaan mereka sangat penting untuk keberkesanan untuk 
mengajar. Salisbury dan McGregor (2002) mendapati bahawa dalam iklim sekolah yang terbuka, pengetua memainkan peranan yang menyokong dan dianggap sebagai tidak autokratik. Guru akan lebih terlibat dengan aktiviti sekolah, akan lebih kolegial, dan memiliki jaringan sokongan sosial yang kuat. Hinds et al. (2015) menunjukkan bahawa sokongan kolegial penting untuk kesejahteraan. Pemboleh ubah seperti kekurangan sokongan dan pengiktirafan, pengasingan profesional, dan interaksi interpersonal yang sukar berkaitan dengan kepuasan kerja yang rendah dan ada risiko tinggi untuk mengalami burnout (Plantiveau et al., 2018).

\section{Kerangka Konseptual Kajian}

Kerangka konsep ini dibina untuk menjelaskan keseluruhan konstruk yang dikaji dalam kajian ini. Konstruk burnout merujuk kepada Maslach dan Jackson (1981) yang menyenaraikan tiga dimensi yang mencirikan burnout iaitu (i) kelesuan emosi (emotional exhaustion), (ii) depersonalisasi (depersonalisation) dan (iii) penurunan prestasi peribadi (personal accomplishment).

Konstruk iklim organisasi sekolah merujuk kepada model Hoy et al. (1991) yang terdiri daripada empat dimensi iaitu (i) kepimpinan kolegial, (ii) tingkah laku profesional guru, (iii) tekanan pencapaian, (iv) kegoyahan institut. Rajah 1 di bawah menunjukkan konsep kajian ini tentang hubungan antara dimensi iklim organisasi sekolah dan dimensi burnout dalam kalangan guru sekolah menengah.

Rajah 1: Kerangka Konseptual Kajian

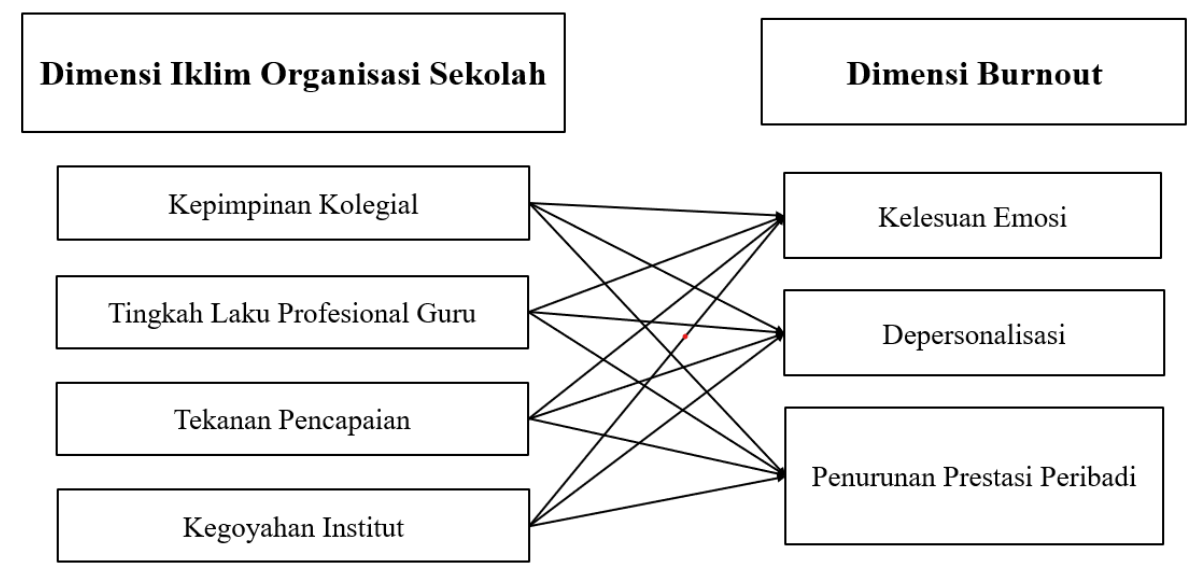

\section{Metod Kajian}

Sampel kajian melibatkan seramai 167 guru di lima buah sekolah menengah di Daerah Subis, Sarawak. Kaedah pensampelan berstrata digunakan untuk memilih responden mengikut kadar atau nisbah. Dengan pensampelan rawak berstrata, setiap strata dalam populasi akan diwakili dan dapatan dan kesimpulan kajian juga akan lebih meyakinkan (Fowler, 2014). Dalam konteks kajian ini, strata merujuk kepada setiap satu sekolah menengah. Tahap iklim organisasi sekolah dan burnout guru diukur menggunakan soal selidik yang telah diadaptasi iaitu Organisational Climate Index (OCI) dan Maslach Burnout Index (MBI). Soal selidik meliputi item yang berkaitan dengan persepi guru tentang iklim sekolah dan tahap burnout diri. Skala Likert empat mata digunakan untuk item iklim organisasi sekolah dengan pemilihan jawapan dari 1 (Jarang) hingga 4 (Selalu) berdasarkan instrumen asal yang dibentuk oleh Hoy et. al. (2002) manakala Skala Likert lima mata digunakan untuk item burnout guru dengan pemilihan jawapan dari 1 (Tiada) hingga 5 (Selalu).

Semua data yang telah dikumpulkan dianalisis menggunakan perisian Statistical Package For Social Sciences (SPSS) Version 26. Analisis deskriptif, analisis regresi berganda stepwise dan analisis korelasi telah digunakan untuk mencapai objektif kajian. Nilai alpha Cronbach untuk instrumen Organisational 
Climate Index (OCI) ialah .780 dan untuk instrumen Maslach Burnout Index (MBI) ialah .760. Keduadua instrumen juga telah melalui kajian rintis dan kesahan gagasan seperti analisis faktor untuk tujuan kesahan instrumen.

\section{Hasil Kajian}

Responden kajian terdiri daripada 167 guru sekolah menengah di daerah Subis, Sarawak. Majoriti responden terdiri daripada guru perempuan $(61.1 \%)$ berbanding responden terdiri daripada guru lelaki (38.9\%). Bagi kelayakan akademik, majoriti responden terdiri daripada 67 orang guru yang berkelayakan sarjana muda $(40.1 \%)$ berbanding 14 orang guru di peringkat sarjana $(8.4 \%)$. Dari segi profil responden berdasarkan pengalaman mengajar didapati bahawa guru yang mempunyai 6-10 tahun ialah merupakan kategori terbanyak responden dengan 78 orang (46.7\%). Ini diikuti oleh seramai 57 orang guru yang mempunyai pengalaman mengajar selama 0 - 5 tahun (34.1\%) dan 23 orang guru yang mempunyai 11-15 tahun (13.8\%). Manakala guru yang mengajar antara 16- 20 tahun ialah seramai 7 orang (4.2\%) yang guru yang mengajar 21 tahun dan ke atas ialah seramai 2 orang (1.2\%). Profil demografi kajian tersebut dipaparkan secara terperinci dalam Jadual 1.

Jadual 1: Maklumat Demografi Responden

\begin{tabular}{llcc}
\hline \multicolumn{1}{c}{ Demografi } & \multicolumn{1}{c}{ Kategori } & $\begin{array}{c}\text { Bilangan } \\
\text { Responden }\end{array}$ & $\begin{array}{c}\text { Peratusan } \\
(\mathbf{\%})\end{array}$ \\
\hline \multirow{3}{*}{ Umur } & 51- 60 tahun & 24 & 14.4 \\
& 41- 50 tahun & 87 & 52.1 \\
Jantina & 31- 40 tahun & 35 & 21.0 \\
& 21- 30 tahun & 21 & 12.6 \\
& Lelaki & 65 & 38.9 \\
& Perempuan & 102 & 61.1 \\
Kelayakan & Ijazah Doktor Falsafah & 4 & 2.4 \\
Akademik & Sarjana & 14 & 8.4 \\
& Sarjana Muda & 67 & 40.1 \\
& Diploma & 49 & 29.3 \\
& Sjil Perguruan & 31 & 18.6 \\
& STP/STPM/HSC & 2 & 1.2 \\
& SPM/ MCE/Sijil & 0 & 0.0 \\
Pengalaman & Vokasional & & 34.1 \\
Mengajar & 0-5 tahun & 57 & 46.7 \\
& 6- 10 tahun & 78 & 13.8 \\
& 11- 15 tahun & 23 & 4.2 \\
\hline
\end{tabular}

Jadual 2 menunjukkan interpretasi skor min yang digunakan bagi analisis statistik deskriptif bagi iklim organisasi sekolah. Skor min 1.00 hingga 1.50 menunjukkan nilai min pada kurang kaitan, skor 1.51 hingga 2.50 adalah min pada tahap rendah, skor 2.51 hingga 3.50 adalah nilai min pada tahap sederhana dan skor min 3.51 hingga 4.00 pada tahap tinggi.

Jadual 2: Jadual Interpretasi Skor Min Likert Empat Mata

\begin{tabular}{cc}
\hline Nilai Min & Interpretasi Skor Min \\
\hline $3.51-4.00$ & Tinggi \\
$2.51-3.50$ & Sederhana \\
$1.51-2.50$ & Rendah \\
$1.00-1.50$ & Kurang kaitan \\
\hline
\end{tabular}


Jadual 3 menunjukkan interpretasi skor min yang digunakan bagi analisis statistik deskriptif bagi burnout guru. Skor min 1.00 hingga 1.50 menunjukkan nilai min pada kurang kaitan, skor 1.51 hingga 2.50 adalah min pada tahap rendah, skor 2.51 hingga 3.50 adalah nilai min pada tahap sederhana dan skor min 3.51 hingga 4.00 pada tahap tinggi.

Jadual 3: Jadual Interpretasi Skor Min Likert Lima Mata

\begin{tabular}{cc}
\hline Nilai Min & Interpretasi Skor Min \\
\hline $4.01-5.00$ & Tinggi \\
$3.01-4.00$ & Sederhana Tinggi \\
$2.01-3.00$ & Sederhana Rendah \\
$1.00-2.00$ & Rendah \\
\hline
\end{tabular}

Sumber : Nunally \& Bernstein (1994)

\section{Ho1 : Tiada tahap burnout yang signifikan dialami oleh guru sekolah menengah daerah Subis, Sarawak.}

Jadual 4 menunjukkan tahap burnout guru sekolah menengah di daerah Subis, Sarawak berada pada tahap sederhana rendah $(\min =2.61, \mathrm{~s} . \mathrm{p}=.466)$, maka $\mathrm{H}_{0} 1$ gagal ditolak.

Jadual 4: Skor Min dan Tahap Burnout Guru Mengikut Dimensi

\begin{tabular}{lccc}
\hline \multicolumn{1}{c}{ Dimensi } & Min & S.P & Interpretasi \\
\hline Dimensi Kelesuan Emosi & 2.55 & .616 & Sederhana Rendah \\
Dimensi Depersonalisasi & 2.62 & .675 & Sederhana Rendah \\
Dimensi Penurunan Pencapaian Diri & 2.67 & .532 & Sederhana Rendah \\
\hline Tahap keseluruhan & $\mathbf{2 . 6 1}$ & $\mathbf{0 . 4 6 6}$ & Sederhana Rendah \\
\hline
\end{tabular}

\section{Ho2 : Tiada tahap iklim organisasi sekolah yang signifikan sekolah menengah daerahSubis, Sarawak.}

Jadual 5 menunjukkan tahap iklim organisasi sekolah menengah di daerah Subis, Sarawak berada pada tahap sederhana $(\min =2.58$, s.p $=.38)$, maka $\mathrm{H}_{0} 2$ gagal ditolak.

Jadual 5: Skor Min dan Tahap Iklim Organisasi Sekolah Mengikut Dimensi

\begin{tabular}{lccc}
\hline \multicolumn{1}{c}{ Dimensi } & Min & S.P & Interpretasi \\
\hline Kepimpinan Kolegial & 2.94 & 0.57 & Sederhana \\
Tingkah Laku Profesional Guru & 3.02 & 0.61 & Sederhana \\
Tekanan Pencapaian & 2.53 & 0.35 & Sederhana \\
Kegoyahan Institut & 1.84 & 0.57 & Rendah \\
\hline Tahap keseluruhan & $\mathbf{2 . 5 8}$ & $\mathbf{0 . 3 8}$ & Sederhana \\
\hline
\end{tabular}

\section{Ho3 : Tiada hubungan signifikan antara iklim organisasi sekolah dengan tahap burnout dalam kalanganguru di daerah Subis, Sarawak.}

Jadual 6 menunjukkan tidak terdapat hubungan yang signifikan antara iklim organisasi sekolah dengan tahap burnout guru dengan nilai $\mathrm{r}=0.053$ dan sig.=.495, $(\mathrm{p}<.05)$. Kekuatan hubungan ialah sangat lemah. Hal ini menunjukkan $\mathrm{H}_{0} 3$ gagal ditolak. Hasil kajian ini telah membuktikan bahawa tidak terdapat perkaitan antara iklim organisasi sekolah dengan tahap burnout guru dengan iklim organisasi sekolah pada tahap sangat lemah pada nilai $r=0.053$. 
Jadual 6: Korelasi Pearson hubungan antara burnout guru dengan iklim organisasi sekolah

\begin{tabular}{clcc}
\hline & & Burnout & Iklim Organisasi Sekolah \\
\hline \multirow{3}{*}{ Burnout } & Korelasi Pearson (r) & 1 & $.053^{* *}$ \\
& Sig. (2 -hujung) & & .495 \\
& $\mathrm{~N}$ & 167 & 167 \\
\hline \multirow{2}{*}{ Iklim Organisasi } & Korelasi Pearson (r) & $.053^{* *}$ & 1 \\
Sekolah & Sig. (2 -hujung) & .495 & \\
& $\mathrm{~N}$ & 167 & 167 \\
\hline
\end{tabular}

\section{Ho31 : Tiada dimensi iklim organisasi sekolah yang paling menyumbang kepada tahap burnout guru sekolah menengah daerah Subis, Sarawak}

Jadual 7 menunjukkan analisis ANOVA daripada analisis regresi berganda stepwise digunakan untuk menguji hipotesis nul 3. Hasil kajian ini menunjukkan kebarangkalian $(\mathrm{Sig}=.600)$ melebihi tahap kesignifikanan ( $\mathrm{p}<.05)$, maka $\mathrm{H}_{0} 3^{1}$ gagal ditolak. Keputusan analisis menunjukkan $[\mathrm{F}(4,162)=0.689$, $\mathrm{p}<0.05$ ] nilai $\mathrm{p}$ yang tidak signifikan. Oleh itu, daripada empat pemboleh ubah bebas yang dimasukkan , tiada yang dapat diterima sebagai model regresi yang signifikan,

Jadual 7: Jadual ANOVA bagi Peramal Dimensi Iklim Organisasi Sekolah

\begin{tabular}{lcccccc}
\hline Model & & $\begin{array}{c}\text { Jumlah } \\
\text { Kuasa } \\
\text { Dua }\end{array}$ & df & $\begin{array}{c}\text { Min } \\
\text { Kuasa } \\
\text { Dua }\end{array}$ & F & Sig. \\
\hline 4 & Regresi & 0.603 & 4 & 0.151 & 0.689 & $.600^{\mathrm{e}}$ \\
\hline & Residual & 35.432 & 162 & 0.219 & & \\
\hline
\end{tabular}

a. Pemboleh ubah bersandar: Burnout

e. Peramal: (Pemalar), Tingkah Laku Profesionalisme Guru, Kepimpinan Kolegial, Tekanan

Pencapaian, Kegoyahan Institut

\section{Perbincangan Kajian}

Secara keseluruhan, tahap iklim organisasi sekolah di sekolah menengah daerah Subis, Sarawak adalah pada tahap yang sederhana. Berdasarkan semua sub dimensi yang dikaji maka sekolah menengah daerah Subis didapati mempunyai tahap kepimpinan kolegial, tingkah laku profesional dan tekanan pencapaian yang sederhana manakala bagi sub dimensi kegoyahan institut pula pada tahap yang rendah. Dapatan kajian ini menyokong kajian terdahulu yang mendapati bahawa tahap iklim organisasi sekolah adalah sederhana di Malaysia oleh Othman dan Kasuma (2017) dalam kajiannya mengenai iklim organisasi sekolah rendah di daerah Sri Aman, Sarawak. Tahap iklim organisasi sekolah yang sederhana menunjukkan kurangnya keterbukaan dalam aspek hubungan antara pihak pentadbiran dengan guru serta pihak ibu bapa. Ini boleh dilihat melalui sub dimensi kepimpinan kolegial dan sub dimensi kegoyahan institut. Sub dimensi kepimpinan kolegial didapati mempunyai min paling tinggi dalam kajian ini berbanding dengan sub dimensi lain. Dapatan ini menyokong Tschannen - Moran dan Gareis (2015) di mana kepercayaan guru terhadap pengetua mempunyai kaitan dengan persepsi guru tentang kepimpinan kolegial dan kegoyahan institut. Persepsi positif tentang kebajikan, kejujuran, keterbukaan, kecekapan, dan nilai moral pengetu semuanya menyumbang secara konsistensi kepada kepercayaan fakulti terhadap pengetua (Handford \& Leithwood, 2013). Kaedah yang paling berkesan untuk menjamin iklim organisasi sekolah yang berjaya dan sihat adalah persekitaran terbuka di mana pihak pentadbir sudi untuk menerima pertanyaan, penyelesaian masalah dan panduan daripada guru (Handford and Leithwood, 2013; Mitchell et al., 2011). 
Secara umumnya, hasil kajian telah menunjukkan bahawa setiap dimensi iklim organisasi sekolah tidak mempunyai hubungan yang signifikan dengan tahap burnout guru sekolah menengah di daerah Subis, Sarawak. Dapatan kajian ini tidak bertepatan dengan hasil kajian lampau (Perrone et al., 2019; Plantiveau et al, 2018; Collie et al., 2012). Shackleton (2019) mendapati faktor-faktor yang paling konsisten berkaitan dengan burnout yang dialami oleh guru adalah persepsi guru terhadap keselamatan dan sokongan sekolah dan sikap pelajar terhadap pembelajaran. Persepsi keselamatan atau sokongan yang rendah dan persepsi yang lemah terhadap minat pelajar untuk belajar dikaitkan dengan tahap burnout yang lebih tinggi tanpa bergantung kepada jantina, etnik, pengalaman, atau aspek persekitaran sekolah yang lain. Kajian tempatan oleh Meor (2011) mendapati hubungan yang signifikan antara iklim kerja dengan tahap burnout guru tetapi tidak mendapati perbezaan yang signifikan di antara tahap burnout dengan jantina dan opsyen guru.

Memandangkan kajian ini tidak menemui hubungan seperti itu dalam pemodelan struktur yang digunakan, satu penjelasan untuk ini adalah bahawa kajian ini tidak merangkumi aspek iklim sekolah yang lain seperti penglibatan murid (Konold et al., 2018), komitmen guru (Othman \& Kasuma, 2017; Suhaili, 2017) dan keberkesanan diri (Zakariya, 2020; Herman et al., 2017; Malinen \& Savolainen, 2016).

\section{Kesimpulan}

Secara keseluruhannya, tahap burnout dan tahap iklim organisasi sekolah di kalangan guru sekolah menengah daerah Subis, Sarawak didapati berada pada tahap yang rendah dan tidak mempunyai hubungan yang signifikan. Isu kesihatan mental masih adalah isu yang sensitif, tetapi sebagai para pendidik, isu ini amat penting kerana profesion keguruan banyak bergantung kepada interaksi sosial dan kesedaran dan keterbukaan untuk berkongsi tentang kesihatan mental masih belum mencapai tahap yang memuaskan. Selain itu, pengetua bertanggungjawab membagi akauntabiliti secara langsung kepada pihak awam di samping menguruskan sekolah mengikut piawai yang ditetapkan. Oleh itu kajian ini mengesyorkan bahawa program pelatihan pengetua dapat membantu pengetua untuk melibatkan suara dan pandangan pihak yang bekerja, belajar, dan mengajar di sekolah, termasuk pihak ibu bapa demi mencapai visi pendidikan sekolah.

\section{Rujukan}

Akhlaq, M., Amjad, M., \& Mehmood, K. (2010). An evaluation of the effects of stress on the job performance of secondary school teachers. Journal of Law and Psychology, 1, 43-54.

Aldrup, K., Klusmann, U., Lüdtke, O., Göllner, R., \& Trautwein, U. (2018). Student misbehavior and teacher well-being: Testing the mediating role of the teacher-student relationship. Learning and Instruction, 58, 126-136. https://doi.org/10.1016/j.learninstruc.2018.05.006

Ali, E., \& Hale, E. (2009). Predicting organizational trust level of school managers and teachers at elementary schools. Procedia-Social and Behavioral Sciences, 1(1), 2180-2190

Ambatong, A., Pilus, N., Abdullah, C. B., \& Christina Andin@Nur Qistin. (2015). Hubungan Karenah Pelajar Dan Beban Tugas Dengan Tahap Stres Guru Di Sekolah Menengah. Master's thesis, Universiti Melaysia Sabah, Faculty of Education. Retrieved from http://eprints.ums.edu.my/21782/

Bakker, A. B., \& Demerouti, E. (2007). The Job Demands-Resources model: state of the art. Journal of Managerial Psychology, 22(3), 309-328. https://doi.org/10.1108/02683940710733115

Bauer, J., Stamm, A., Virnich, K., Wissing, K., Müller, U., Wirsching, M., \& Schaarschmidt, U. (2005). Correlation between burnout syndrome and psychological and psychosomatic symptoms among teachers. International Archives of Occupational and Environmental Health, 79(3), 199 204. https://doi.org/10.1007/s00420-005-0050-y

Bianchi, R., Schonfeld, I. S., \& Laurent, E. (2015). Burnout-depression overlap: A review. Clinical Psychology Review, 36, 28-41.

Boström, M., Björklund, C., Bergström, G., Nybergh, L., Schäfer Elinder, L., Stigmar, K., Wåhlin, C., Jensen, I., \& Kwak, L. (2019). Health and Work Environment among Female and Male Swedish 
Elementary School Teachers-A Cross-Sectional Study. International Journal of Environmental Research and Public Health, 17(1), 227. https://doi.org/10.3390/ijerph17010227

Bottiani, J. H., Duran, C. A. K., Pas, E. T., \& Bradshaw, C. P. (2019). Teacher stress and burnout in urban middle schools: Associations with job demands, resources, and effective classroom practices. Journal of School Psychology, 77, 36-51. https://doi.org/10.1016/j.jsp.2019.10.002

Chaplain, R. P. (2008). Stress and psychological distress among trainee secondary teachers in England. Educational Psychology, 28(2), 195-209. https://doi.org/10.1080/01443410701491858

Choi, B. (2018). Job strain, long work hours, and suicidal ideation in US workers: a longitudinal study. International Archives of Occupational and Environmental Health,91(7), 865-875. https://doi.org/10.1007/s00420-018-1330-7

Cohen J, Pickeral T and McCloskey M (2009) Assessing school climate. Educational Leadership 74: 45-48.

Collie, R. J., Shapka, J. D., dan Perry, N. E. (2012). School climate and social-emotional learning: Predicting teacher stress, job satisfaction, and teaching efficacy. Journal of Educational Psychology, 104(4), 1189-1204. https://doi.org/10.1037/a0029356

Conley, S., \& You, S. (2013). Role stress revisited. Educational Management Administration \& Leadership, 42(2), 184-206. https://doi.org/10.1177/1741143213499264

De Simone S, Cicotto G, Lampis J. Occupational stress, job satisfaction and physical health in teachers. Revue Europe'enne de Psychologie Appliquée/European Review of Applied Psychology 2016; 66:65-77.

Dickson, M., Smith, M. W., Grojean, M. C., \& Ehrhart, M. W. (2001). An organizational climate regarding ethics: The outcome of leader values and the practices that reflect them. Leadership Quarterly, 12, 197-214.

Dipaola, M. F., \& Hoy, W. K. (2012). Principals improving instruction : supervision, evaluation, and professional development. Information Age Publishing.

Dorman, J. (2003). Testing a Model for Teacher Burnout. Australian Journal of Educational \& Developmental Psychology, 3, 35-47.

Ford, T. G., Olsen, J., Khojasteh, J., Ware, J., \& Urick, A. (2019). The effects of leader support for teacher psychological needs on teacher burnout, commitment, and intent to leave. Journal of Educational Administration, 57(6), 615-634. https://doi.org/10.1108/jea-09-2018-0185

Gaias, L. M., Lindstrom Johnson, S., Bottiani, J. H., Debnam, K. J., \& Bradshaw, C. P. (2019). Examining teachers' classroom management profiles: Incorporating a focus on culturally responsive practice. Journal of School Psychology, 76, 124-139. https://doi.org/10.1016/j.jsp.2019.07.017

Ghavifekr, S., \& Pillai, N. S. (2016). The relationship between school's organizational climate and teacher's job satisfaction: Malaysian experience. Asia Pacific Education Review, 17(1), 87-106. https://doi.org/10.1007/s12564-015-9411-8

Goddard, Y., Goddard, R., \& Kim, M. (2015). School Instructional Climate and Student Achievement: An Examination of Group Norms for Differentiated Instruction. American Journal of Education, 122(1), 111-131. https://doi.org/10.1086/683293

Grandey, A. A., \& Gabriel, A. S. (2015). Emotional Labor at a Crossroads: Where Do We Go from Here? Annual Review of Organizational Psychology and Organizational Behavior, 2(1), 323349. https://doi.org/10.1146/annurev-orgpsych-032414-111400

Grayson, J. L., dan Alvarez, H. K. (2008). School climate factors relating to teacher burnout: A mediator model. Teaching and Teacher Education,24,1349-1363.

Gregory, A., Cornell, D., Fan, X., Sheras, P., Shih, T., \& Huang, F. (2010). Authoritative school discipline: High school practices associated with lower student bullying and victimization. Journal of Educational Psychology, 102, 483-496. doi:10.1037/a0018562

Halim, N., S. (2013) Menentusahkan faktor tekanan kerja guru sekolah menengah gred A daerah Batu Pahat. Masters thesis, Universiti Tun Hussein Onn Malaysia. http://eprints.uthm.edu.my/id/eprint/4199/

Handford, V., \& Leithwood, K. (2013). Why teachers trust school leaders. Journal of Educational Administration, 51(2), 194-212.

Hattie, J. (2017). Visible learning for teachers : Maximizing impact on learning. Routledge.

Heinnemann, L. V., \& Heinemann, T. (2017). Burnout Research. SAGE Open, 7(1), 215824401769715. https://doi.org/10.1177/2158244017697154 
Herman, K. C., Hickmon-Rosa, J., \& Reinke, W. M. (2017). Empirically Derived Profiles of Teacher Stress, Burnout, Self-Efficacy, and Coping and Associated Student Outcomes. Journal of Positive Behavior Interventions, 20(2), 90-100. https://doi.org/10.1177/1098300717732066

Hinds, E., Jones, L B., Gau, J. M., Forrester, K. K., \& Biglan, A. (2015). Teacher Distress And The Role Of Experiential Avoidance. Psychology in the Schools, 52(3), 284-297. https://doi.org/10.1002/pits. 21821

Hoge, D. R., Smit, E. K., \& Hanson, S. L. (1990). School experiences predicting changes in selfesteem of sixth and seventh-grade students. Journal of Educational Psychology, 82, 117-127. doi:10.1037//0022-0663.82.1.117

Hoy, W. K. (1972). Dimensions of student alienation and characteristics of public high schools. Interchange, 3, 36-52.

Hoy, W. K., \& Miskel, C. G. (2008). Educational administration: Theory, research, and practice (8th ed.). New York: McGraw-Hill.

Hoy, W. K., \& Sabo, D. J. (1998). Quality Middle Schools: Open and Healthy. Thousand Oaks, CA: Corwin Press.

Hoy, W. K., Sweetland, S. R., \& Smith, P. A. (2002). Toward an organizational model of achievement in high schools: the significance of collective efficacy. Educ. Administrat. Q. 38, 77-93. doi: 10.1177/0013161X02381004

Hoy, W. K., Tarter, C. J., \& Kottkamp, R. B. (1991). Open schools/healthy schools: Measuring organizational climate. Beverly Hills, CA: Sage.

Hoy, W.K. \& Tarter, C.J. (2004) Organizational Justice in Schools: No Justice without Trust. International Journal of Educational Management, 18, 250-259. http://dx.doi.org/10.1108/09513540410538831

Hu, B. Y., Li, Y., Wang, C., Reynolds, B. L., dan Wang, S. (2019). The relation between school climate and preschool teacher stress: The mediating role of teachers' self-efficacy. Journal of Educational Administration, 57(6), 748-767. doi:10.1108/JEA-08-2018-0146

Hulsheger, U.R. and Schewe, A.F. (2011) On the costs and benefits of emotional labour: A metaanalysis of decades of research. Journal of Occupational Psychology 16: 361-389.

Ingersoll, R. M. (2002, August 15). High turnover plagues schools. USA Today, p. 13A.

Ivancevich, J. M., Konopaske, R., \& Matteson, M. T. (2008). Organizational behavior and management (8th ed.). New York: McGraw Hill.

Jarvis, M. (2002).Teacher Stress: A Critical Review of Recent Findings and Suggestions for Future Research Directions, .http://www.isma.org.uk/stressnw/teachstress.htm

Johnson, S., Cooper, C., Cartwright, S., Donald, I., Taylor, P., \& Millet, C. (2005). The experience of work-related stress across occupations. Journal of Managerial Psychology, 20(2), 178-187. https://doi.org/10.1108/02683940510579803

Kinman G, Wray, S. and Strange, C. (2011) Emotional labour, burnout and job satisfaction in UK teachers: The role of workplace social support. Educational Psychology 31: 843-856.

Kokkinos C. M. (2007). Job stressors, personality and burnout in primary school teachers. The British Journal Of Educational Psychology, 77(Pt 1), 229-243. https://doi.org/10.1348/000709905X90344

Kovess-Masféty, V., Rios-Seidel, C., \& Sevilla-Dedieu, C. (2007). Teachers' mental health and teaching levels. Teaching and Teacher Education, 23(7), 1177-1192. https://doi.org/10.1016/j.tate.2006.07.015

Kunter M, Frenzel, A., Nagy, G., et al. (2011) Teacher enthusiasm: Dimensions and context $\begin{array}{lllll}\text { specificity.Contemporary } & \text { Educational } & \text { Psychology } & 369-301 .\end{array}$ https://doi.org/10.1016/j.cedpsych.2011.07.001

Kuperminic, G. P., Leadbeater, B. J., \& Blatt, S. J. (2001). School social climate and individual differences in vulnerability to psychopathology among middle school students. Journal of School Psychology, 39, 141-159.

Kyriacou, C., \& Sutcliffe, J. (1978). Teacher stress: Prevalence, sources, and symptoms. British Journal of Educational Psychology, 48(2), 159-167. https://doi.org/10.1111/j.20448279.1978.tb02381.x

Larson, K. E., Nguyen, A. J., Orozco Solis, M. G., Humphreys, A., Bradshaw, C. P., \& Lindstrom Johnson, S. (2020). A systematic literature review of school climate in low and middle income 
DOI: https://doi.org/10.47405/mjssh.v6i2.663

countries. International Journal of Educational Research, 102, 101606. https://doi.org/10.1016/j.ijer.2020.101606

LaRusso, M., Romer, D., \& Selman, R. (2008). Teachers as builders of respectful school climates: Implications for adolescent drug use norms and depressive symptoms in high school. Journal of Youth \& Adolescence, 37, 386-398. doi:10.1007/ s10964-007-9212-4

Lavian, R. H. (2011). The impact of organizational climate on burnout among homeroom teachers and special education teachers (full classes/individual pupils) in mainstream schools. Teachers and Teaching, 18(2), 233-247. https://doi.org/10.1080/13540602.2012.632272

Lim, S., \& Eo, S. (2014). The mediating roles of collective teacher efficacy in the relations of teachers' perceptions of school organizational climate to their burnout. Teaching and Teacher Education, 44, 138-147. https://doi.org/10.1016/j.tate.2014.08.007

Lingard, B., Thompson, G., \& Sellar, S. (Eds.). (2016). National testing in schools: an Australian assessment. Routledge.

Malinen, O.-P., \& Savolainen, H. (2016). The effect of perceived school climate and teacher efficacy in behavior management on job satisfaction and burnout: A longitudinal study. Teaching and Teacher Education, 60, 144-152. https://doi.org/10.1016/j.tate.2016.08.012

Maslach, C. (2003). Job Burnout. Current Directions in Psychological Science, 12(5), 189-192. https://doi.org/10.1111/1467-8721.01258

Maslach, C., \& Jackson, S. E. (1981). The measurement of experienced burnout. Journal of Organizational Behavior, 2(2), 99-113. https://doi.org/10.1002/job.4030020205

McMurray, A. J., Pace, R. W., \& Scott, D. (2004). Research: A commonsense approach. Southbank, Victoria, Australia: Thomson Social Science Press.

Meor, M. M. H (2011). Iklim kerja dan tahap burnout guru-guru pendidikan jasmani sekolah menengah dalam daerah Kuala Kangsar. Masters thesis, Universiti Kebangsaan Malaysia. Diambil dari http://ptsldigital.ukm.my:8080/vital/access/manager/Repository/ukmvital:74392?site_name=Restr icted $\% 20$ Site $\% 20[\log$ in $\% 20$ required]

Mitchell, M. M., \& Bradshaw, C. P. (2013). Examining classroom influences on student perceptions of school climate: The role of classroom management and exclusionary discipline strategies. Journal of School Psychology, 51(5), 599-610. https://doi.org/10.1016/j.jsp.2013.05.005

Mohamad, N., (2015). Tekanan kerja dalam kalangan guru : Kajian di sebuah sekolah menengah Daerah Kluang Johor Darul Takzim. Masters thesis, Universiti Utara Malaysia. http://etd.uum.edu.my/5522/

Nieuwoudt, A. M. (2012). Confirmatory factor analysis of the organizational climate measure: A South African perspective. Master's dissertation. University of Pretoria, South Africa. Retrieved from http://upetd.up.ac.za/thesis/submitted/etd05152012-122735/unrestricted/dissertation.pdf.

Othman, C., \& Kasuma, J. (2017). Relationship of school climate dimensions and teachers' commitment. International Journal of ADVANCED AND APPLIED SCIENCES, 4(3), 94-100. https://doi.org/10.21833/ijaas.2017.03.015

Othman, Z \& Sivasubramaniam, V. (2019). Depression, Anxiety, and Stress among Secondary School Teachers in Klang, Malaysia. International Medical Journal (1994). 26. 71-74. Diambil dari http://eprints.usm.my/id/eprint/45290

Perrone, F., Player, D., \& Youngs, P. (2019). Administrative Climate, Early Career Teacher Burnout, and Turnover. Journal of School Leadership, 29(3), 191-209. https://doi.org/10.1177/1052684619836823

Petrie, K and Devcich, J and Fitzgerald, H (2018) Working towards inclusive physical education in a primary school: 'some days I just don't get it right'. Physical Education and Sport Pedagogy, 23 (4). pp. 345-357. ISSN 1740-8989 DOI: https://doi.org/10.1080/17408989.2018.1441391

Plantiveau, C., Dounavi, K., dan Virués-Ortega, J. (2018). High levels of burnout among early-career board-certified behavior analysts with low collegial support in the work environment, European Journal of Behavior Analysis, DOI: 10.1080/15021149.2018.1438339

Reinke, W. M., Herman, K. C., \& Stormont, M. (2012). Classroom-Level Positive Behavior Supports in Schools Implementing SW-PBIS. Journal of Positive Behavior Interventions, 15(1), 39-50. https://doi.org/10.1177/1098300712459079

Riduwan (2012) Skala Pengukuran Variable-variable: Penelitian. Alfabeta, Bandung. 
Rooney, E. (2015). 'I'm just going through the motions": High-Stakes Accountability and Teachers' Access to Intrinsic Rewards. American Journal of Education, 121(4), 475-500. https://doi.org/10.1086/681923

Saeki, E., Segool, N., Pendergast, L., \& von der Embse, N. (2018). The influence of test-based accountability policies on early elementary teachers: School climate, environmental stress, and teacher stress. Psychology in the Schools, 55(4), 391-403. https://doi.org/10.1002/pits.22112

Shackleton, N., Bonell, C., Jamal, F., Allen, E., Mathiot, A., Elbourne, D., \& Viner, R. (2019). Teacher Burnout and Contextual and Compositional Elements of School Environment. Journal of School Health, 89(12), 977-993. https://doi.org/10.1111/josh.12839

Shen, B., McCaughtry, N., Martin, J., Garn, A., Kulik, N., \& Fahlman, M. (2015). The relationship between teacher burnout and student motivation. British Journal of Educational Psychology, 85(4), 519-532. https://doi.org/10.1111/bjep.12089

Shkëmbi, F., Melonashi, E., \& Fanaj, N. (2015). Workplace Stress Among Teachers in Kosovo. SAGE Open, 5(4), 215824401561461. https://doi.org/10.1177/2158244015614610

Shoval, E., Erlich, I., \& Fejgin, N. (2010). Mapping and interpreting novice physical education teachers' self-perceptions of strengths and difficulties. Physical Education \& Sport Pedagogy, 15(1), 85-101. https://doi.org/10.1080/17408980902731350

Skaalvik, E. M., \& Skaalvik, S. (2009). Does school context matter? Relations with teacher burnout and job satisfaction. Teaching and Teacher Education, 25(3), 518-524. https://doi.org/10.1016/j.tate.2008.12.006

Stoeber, J., \& Rennert, D. (2007). Perfectionism in school teachers: Relations with stress appraisals, coping styles, and burnout.Anxiety, Stress, \& Coping, 21(1), 37-53. https://doi.org/10.1080/10615800701742461

Tajulashikin, J., Fazura, M. N., \& Mohd Burhan, I. (2013). Faktor-faktor penentu stress dalam kalangan guru sekolah rendah mubaligh di Kuala Lumpur. Jurnal Kurikulum \& Pengajaran Asia Pasifik, 1(2): 1-11.

Thapa, A., Cohen, J., Guffey, S., \& Higgins-D'Alessandro, A. (2013). A Review of School Climate Research. Review of Educational Research, 83(3), 357-385. https://doi.org/10.3102/0034654313483907

Tschannen-Moran, M., \& Gareis, C. R. (2015). Faculty trust in the principal: an essential ingredient in high-performing schools. Journal of Educational Administration, 53(1), 66-92. https://doi.org/10.1108/jea-02-2014-0024

Vos, D., van der Westhuizen, P. C., Mentz, P. J., \& Ellis, S. M. (2012). Educators and the quality of their work environment: an analysis of the organisational climate in primary schools. South African Journal of Education, 32(1), 56-68. https://doi.org/10.15700/saje.v32n1 a520

Wahab, N. A., (2018). Kualiti pengajaran, prestasi kerja, tekanan kerja dan hubungan dengan beban tugas guru sekolah menengah di negeri Sabah. Doctoral thesis, University Malaysia Sabah. Dilayari http://eprints.ums.edu.my/22484/

Way, N., Reddy, R., \& Rhodes, J. (2007). Students' perceptions of school climate during the middle school years: Associations with trajectories of psychological and behavioral adjustment. American Journal of Community Psychology, 40, 194-213. doi:10.1007/s10464-007-9143-y

Zakariya, Y. F. (2020). Effects of school climate and teacher self-efficacy on job satisfaction of mostly STEM teachers: a structural multigroup invariance approach. International Journal of STEM Education, 7(1). https://doi.org/10.1186/s40594-020-00209-4

Zhang, L., Zhao, J., Zheng, H., Xiao, Y., Chen, M., Chen, D., \& Xiao, H. (2014). Mental health and burnout in primary and secondary school teachers in the remote mountain areas of Guangdong Province in the People's Republic of China. Neuropsychiatric Disease and Treatment, 10, 123. https://doi.org/10.2147/ndt.s56020 